\title{
The effect of thermal pre-treatment on cassava rhizome properties for utilizing as green fuel in gasification
}

\author{
Punchaluck Sirinwaranon ${ }^{1}$, Duangduen Atong ${ }^{2}$, and Viboon Sricharoenchaikul ${ }^{3, *}$ \\ ${ }^{1}$ Interdisciplinary Program in Environmental Science, Graduate School, Chulalongkorn University, Bangkok, Thailand, 10330 \\ ${ }^{2}$ National Metal and Materials Technology Center (MTEC), National Science and Technology Development Agency (NSTDA), \\ Thailand Science Park, Pathum Thani, Thailand, 12120 \\ ${ }^{3}$ Department of Environmental Engineering, Faculty of Engineering, Chulalongkorn University, Bangkok, Thailand, 10330
}

\begin{abstract}
Cassava rhizome (CR) was torrefied to provide superior solid fuel quality for further gasification process. The torrefaction was carried out in the absence of oxygen at $220,240,260$, and $280^{\circ} \mathrm{C}$ with a fixed residence time. Solid fuel after torrefaction has a higher calorific value from that of reduced volatile matters. The optimum energy yield of torrefied CR is $88.16 \%$ at $260^{\circ} \mathrm{C}$. The heating value of $20.86 \mathrm{MJ} / \mathrm{kg}$ for a torrefied product can be achieved compared to $15.37 \mathrm{MJ} / \mathrm{kg}$ for untreated CR. The subsequent gasification of torrefied $\mathrm{CR}$ at temperature of $800^{\circ} \mathrm{C}$ yielded the highest gas product of 65 wt.\%. The carbon and hydrogen conversions into $\mathrm{CO}$ and $\mathrm{H}_{2}$ were $14.28 \%$ and $29.95 \%$, respectively. Synthesis gas (syngas) from the conversion maintained the $\mathrm{H}_{2} / \mathrm{CO}$ ratio of around 2-2.50, which is suitable for the Fischer-Tropsch process or can be used as the feedstock for petrochemical industry.
\end{abstract}

\section{Introduction}

The torrefaction treatment or mild pyrolysis is conducted at a temperature of $200-300^{\circ} \mathrm{C}$ in an inert atmosphere, i.e., in the absence of oxygen. During torrefaction, parts of the original component in the biomass, such as volatile compounds, lignocellulosic materials (hemicellulose, cellulose and lignin), are decomposed at different temperatures. Hemicellulose decomposes within a temperature range of $225-325^{\circ} \mathrm{C}$, cellulose within 270 $350^{\circ} \mathrm{C}$, and lignin gradually over a range of $250-500^{\circ} \mathrm{C}$ [1]. Therefore, torrefaction may render the biomass into an attractive solid fuel with properties for further thermal conversion processes along with the ease of long-distance transportation, long term storage, and palletization [2, 3]. Cassava rhizome (CR) is the woody part between the stalk and the tapioca tuberous root. The carbon content and heating value of the cassava rhizome are suitable as renewable energy sources. Sirijanusorn et al. (2013) pyrolyzed CR in a counter-rotating twin screw reactor to obtain maximum bio-oil yield of $43.05 \mathrm{wt} \%$ and a minimum char yield of approximately $5 \mathrm{wt} . \%$. However, the acidity of the bio-oil obtained from the twin-screw

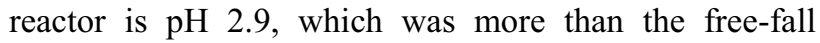
reactor type ( $\mathrm{pH} 3.50)$. Homchat et al. (2012) conducted a slow pyrolysis of fresh and dried CR with a large-scale metal kiln which resulted in less charcoal in the case of fresh CR (10-13 wt.\%) due to the moisture content. However, this bio-oil product also contained high oxygenated compounds as acids with low $\mathrm{pH}$ value.

Further improvement of fuel product properties from CR thermal conversion can be accomplished by upgrading the input raw materials via torrefaction. In this work, the effect of different temperatures of cassava rhizome torrefaction was studied using a batch reactor to produce quality solid raw materials which were, subsequently, subjected to gasification to obtain quality fuel gas product.

\section{Experimental}

\subsection{Biomass sample}

The cassava rhizome (CR) used is agricultural waste from the tapioca field from the Nakon-sawan province in Thailand. The picture of the CR samples is shown in Fig. 1. The CR was air-dried for $24 \mathrm{~h}$ to reduce the moisture and then grinded and sieved to $0.850 \mathrm{~mm}-2 \mathrm{~mm}$. The analysis of moisture content, volatile matter, and ash was performed by ASTM E-871, ASTM E-872, ASTM E1755-01, respectively. The elemental analysis was performed using the CHNO micro analyzer following the ASTM F-3174 method.

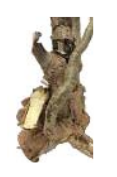

(a)

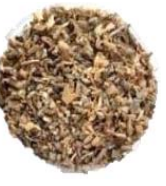

(b)
Fig. 1. Raw materials: (a) As received CR and (b) Ground and sieved CR $0.85-2 \mathrm{~mm}$.

\subsection{Torrefaction system}

\footnotetext{
Corresponding author: viboon.sr@chula.ac.th
} 
The reactor vessel was a vertical stainless-steel tube with an internal diameter of $50 \mathrm{~mm}$ and a height of $500 \mathrm{~mm}$. The temperature control was achieved by means of proportional-integral-derivative (PID) controller in which the reactor temperature was measured by the Ktype thermocouples placed at the top, middle, and bottom sections of the reactor. During each run, the CR was fed into the reactor in $90 \mathrm{~g}$. $\mathrm{N}_{2}$ flow of $1 \mathrm{l} / \mathrm{min}$ was used to purge the reactor for $15 \mathrm{~min}$ before beginning the experiment and continuously applied to ensure ideal pyrolysis atmosphere in the reactor throughout the trial. The furnace was then activated and controlled to reach the final torrefaction temperature of 220, 240, 260, and $280^{\circ} \mathrm{C}$ and then held for $30 \mathrm{~min}$. After the completion of the torrefaction process, the furnace was turned off and left to cool to ambient the temperature. Then, the torrefied CR was collected. The samples were weighed and stored in an airtight container to avoid reabsorption of moisture. The liquid product, condensed in two conical flasks, was collected for further analysis.

\subsection{Gasification system}

In this study, a free-fall gasifier was utilized. The main reactor setup was composed of a biomass feeder, carrier gas controller, electrical furnace, stainless-steel reactor, condenser, and gas collection system. Reaction temperature was $600-800^{\circ} \mathrm{C}$. The ratio of $\mathrm{N}_{2}$ and $\mathrm{O}_{2}$ was adjusted to a target equivalence ratio $(\mathrm{ER}=0.4)$. The $\mathrm{CR}$ was semi-continuously fed into the system at a rate of 1.0 $\mathrm{g} / \mathrm{min}$ for a 20 -min run. The liquid products, such as tar and other heavy hydrocarbons as well as condensate, were retained in condensers and gas washers. The gaseous product was analyzed with a portable gas analyzer (Gasboard-3100p) which is capable of continuous real-time qualification of $\mathrm{CO}_{2}, \mathrm{CO}, \mathrm{H}_{2}, \mathrm{CH}_{4}$ and $\mathrm{C}_{\mathrm{m}} \mathrm{H}_{\mathrm{n}}$. The solid product from the gasification process was settled at the bottom of the reactor and, later, collected for further analysis.

\section{Results and discussion}

\subsection{The solid fuel properties of torrefied CR}

The component, proximate, and ultimate analyses of CR when compared with other studies were as listed in Table 1. The CR sample used in this work showed proximate and ultimate analysis values comparable with previous works $[3,5]$. The $\mathrm{CR}$ raw materials have less fixed carbon (10-20 wt\%), more volatiles (65-81 wt \%). Lower heating value (LHV) range in CR was $15-20 \mathrm{MJ} / \mathrm{kg}$ which similar to typical biomass. The yield of the liquid product was improved from $6.95 \mathrm{wt} \%$ to $11.72 \mathrm{wt} \%$ when the temperature increased from $220^{\circ} \mathrm{C}$ to $280^{\circ} \mathrm{C}$. The yields of the gaseous product were relatively small for the torrefaction at this temperature range.

The proximate analysis of the torrefied $\mathrm{CR}$ at temperatures of $220,240,260$, and $280^{\circ} \mathrm{C}$ are shown in Fig. 1. It was found that the removal of volatile matter and moisture content led to a decrease in the $\mathrm{O} / \mathrm{C}$ ratio. Volatile matter refers to the part of the CR that was released when the $\mathrm{CR}$ was heated at $220-280^{\circ} \mathrm{C}$. The loss of volatile matter of $\mathrm{CR}$ was around $40 \mathrm{wt} \%$, which resulted in higher fixed carbon content of 37-40 wt.\%. The ash content increased from 5.22-15.26 wt $\%$ after torrefaction at $220-280^{\circ} \mathrm{C}$. The effect of the torrefaction temperature is more pronounced than other factors as the volatile matter content of the torrefied $\mathrm{CR}$ decreased significantly with an increase in the temperature.

Table 1. Characteristics of Cassava Rhizome.

\begin{tabular}{|l|c|c|c|}
\hline Properties analysis & This work & {$[\mathbf{3}]$} & {$[\mathbf{5}]$} \\
\hline $\begin{array}{l}\text { Proximate } \\
\text { (wt.\%) }\end{array}$ & & & \\
\hline Moisture & 8.60 & 8.80 & 0.83 \\
\hline Ash & 5.22 & 11.20 & 3.72 \\
\hline Volatile matter & 74.70 & 65.00 & 76.21 \\
\hline Fixed carbon & 12.02 & 15.00 & 20.08 \\
\hline Ultimate analysis (wt.\%) & & & \\
\hline C & 37.60 & 49.50 & 52.33 \\
\hline H & 5.41 & 6.50 & 5.95 \\
\hline N & 0.37 & 1.10 & 1.03 \\
\hline S & 0.15 & - & 0.08 \\
\hline O & 37.50 & 42.90 & 40.62 \\
\hline Other* & 18.97 & - & - \\
\hline
\end{tabular}

The fixed carbon, ash and carbon content of the torrefied $\mathrm{CR}$ also increased with the temperature. Likewise, the previous studies with torrefied biomass, such as reed canary, wheat straw, eucalyptus wood and bark, resulted in a higher content of the ash remaining in the biomass samples [4-5]. However, the moisture content in the torrefied $\mathrm{CR}$ in the present study was less than $0.20 \mathrm{wt} \%$ with a torrefaction temperature of $280^{\circ} \mathrm{C}$.

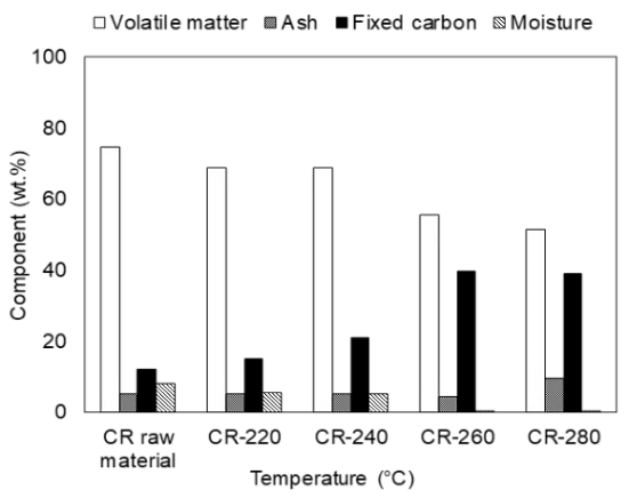

Fig. 1. Proximate analysis of $\mathrm{CR}$ and torrefied products.

The results of the mass yield, energy yield, and energy density (ratio) from the present study are presented in Table 2. During torrefaction, only volatile matter with low calorific value are removed as most of the CR mass loss, though this does not result in any significant energy reduction. Here, $31.97 \mathrm{wt} \%$ of the weight loss occurs during the torrefaction at high temperatures $\left(280^{\circ} \mathrm{C}\right)$. Some authors have already reported greater weight loss when lignocellulosic samples were torrefied above $250^{\circ} \mathrm{C}$. This can be because each pseudo component (hemicellulose, cellulose and lignin) is particularly affected at temperatures above $250^{\circ} \mathrm{C}$.

The gas yield during torrefaction increased monotonously with an increase in the reaction temperature. The energy density ratio altered with the temperature in which the 
optimal temperature of $260^{\circ} \mathrm{C}$ and $280^{\circ} \mathrm{C}$ gave the energy density ratios of 1.36 and 1.28 , respectively. The LHV of the CR raw material was $15.37 \mathrm{MJ} / \mathrm{kg}$. After torrefaction at temperatures of $220^{\circ} \mathrm{C}, 240^{\circ} \mathrm{C}, 260^{\circ} \mathrm{C}$, and $280^{\circ} \mathrm{C}$, LHVs of $16.45 \mathrm{MJ} / \mathrm{kg}, 15.64 \mathrm{MJ} / \mathrm{kg}, 20.86 \mathrm{MJ} / \mathrm{kg}$, and $17.90 \mathrm{MJ} / \mathrm{kg}$ were obtained, respectively. The relationship between the LHV, the energy yield and the mass yield with the torrefaction temperature is shown in Table 2 .

Table 2. Properties of CR torrefaction at different temperatures.

\begin{tabular}{|l|c|c|c|c|}
\hline Properties & $\begin{array}{c}\text { CR- } \\
\mathbf{2 2 0}\end{array}$ & $\begin{array}{c}\text { CR- } \\
\mathbf{2 4 0}\end{array}$ & $\begin{array}{c}\text { CR- } \\
\mathbf{2 6 0}\end{array}$ & $\begin{array}{c}\text { CR- } \\
\mathbf{2 8 0}\end{array}$ \\
\hline Mass yield (wt.\%) & 92.54 & 89.10 & 79.41 & 68.03 \\
\hline Energy yield (\%) & 99.07 & 96.98 & 88.16 & 77.81 \\
\hline Energy density ratio & 1.07 & 1.12 & 1.36 & 1.28 \\
\hline LHV(MJ/kg) & 16.45 & 17.30 & 20.86 & 19.70 \\
\hline C & 45.45 & 45.39 & 51.25 & 49.39 \\
\hline H & 4.22 & 4.22 & 3.42 & 3.55 \\
\hline N & $<0.01$ & 0.29 & 0.12 & 0.59 \\
\hline O & 50.33 & 50.11 & 45.22 & 46.47 \\
\hline
\end{tabular}

This ultimate analysis can also be used to classify the biomass using the Van Krevelen diagram (Fig. 2). The Van Krevelen diagram was established with the samples' $\mathrm{O} / \mathrm{C}$ ratio as $\mathrm{X}$-axis and $\mathrm{H} / \mathrm{C}$ ratio in $\mathrm{Y}$-axis. The $\mathrm{O} / \mathrm{C}$ and $\mathrm{H} / \mathrm{C}$ ratios decrease parallel to the torrefaction temperature $220-260^{\circ} \mathrm{C}$. The effect of torrefaction on major chemical elements in the samples is significant. Before the torrefaction, the $\mathrm{CR}$ raw material has the highest $\mathrm{O} / \mathrm{C}$ and $\mathrm{H} / \mathrm{C}$ atomic ratio. $\mathrm{CR}$ has an $\mathrm{O} / \mathrm{C}$ ratio of 1.12 and $\mathrm{H} / \mathrm{C}$ ratio of 1.73 . With torrefied $\mathrm{CR}$ at $220^{\circ} \mathrm{C}$, these ratios are reduced to 0.63 and 1.11 , respectively. The $\mathrm{O} / \mathrm{C}$ ratio reaches a value of 0.66 and the $\mathrm{H} / \mathrm{C}$ ratio a value of 0.79 for CR-260. This result is related to the decreasing of oxygen content in the torrefied $\mathrm{CR}$, for $\mathrm{O} / \mathrm{C}$ in $\mathrm{CR}$ raw material was 1.12 to 0.66 when torrefied at $260^{\circ} \mathrm{C}$.

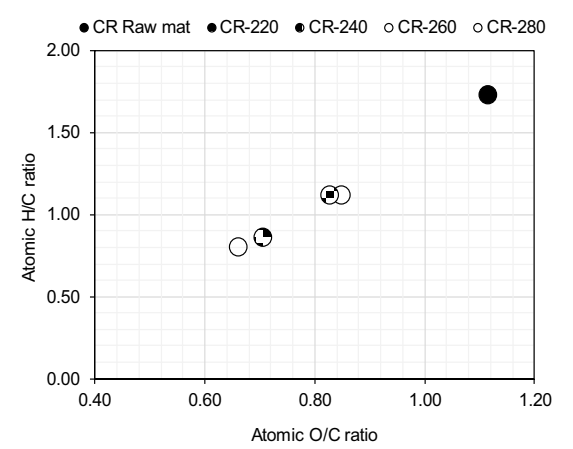

Fig. 2. Van Krevelen plot for $\mathrm{CR}$ and torrefied $\mathrm{CR}$ at $220-280^{\circ} \mathrm{C}$.

The relation between the CR heating value and hydrogenoxygen content can be confirmed with the heating value of torrefied CR, as shown in Table 2. The Nitrogen content in the $\mathrm{CR}$ raw material was reduced by more than $50 \%$, from 0.37 to 0.12 at a temperature of $260^{\circ} \mathrm{C}$ and was not present when torrefied at $220^{\circ} \mathrm{C}$. The $\mathrm{NO}_{\mathrm{x}}$ formation during torrefaction and gasification is negligible due to the low nitrogen element in CR. The results indicated that the heating value of torrefied $\mathrm{CR}$ increases by more than $35 \%$ when processed at $260^{\circ} \mathrm{C}$ for $30 \mathrm{~min}$.

\subsection{Gasification of torrefied CR}

The major component of gases from gasification are $\mathrm{CO}$, $\mathrm{H}_{2}$ and $\mathrm{CO}_{2}$. The product yields from gasification were as illustrated in Fig. 3. The gas quantity derived from utilizing CR-260 as raw material increased to 55.45, 60.21 and $67.00 \mathrm{wt} . \%$ for temperatures of 600,700 and $800^{\circ} \mathrm{C}$, respectively, which are $10-15 \%$ less than that of the $\mathrm{CR}$ raw material. It is important to note that the pyrolysis step that occurs during the process also contributes to the $\mathrm{CO}_{2}, \mathrm{CO}, \mathrm{CH}_{4}$ and lower amounts of $\mathrm{H}_{2}$ and other hydrocarbons. These result from the primary decomposition of the solid fuel and secondary reactions of the volatiles. This is mainly due to the loss of volatiles from the prior torrefaction process. Similarly, the gasification of CR-260 also resulted in a lesser amount of liquid yields (9.50-19.50 wt.\%). It can be noted that increasing in gas yields with temperature is mainly from the greater decomposition of liquid products. These volatile hydrocarbons are converted to flue gas. The remaining non-volatile material, containing high carbon content, is referred to as solid or char. Here, the solid product was measured from $34.15 \%-25.50 \%$ as temperature the fell from $800^{\circ} \mathrm{C}$ to $600^{\circ} \mathrm{C}$.

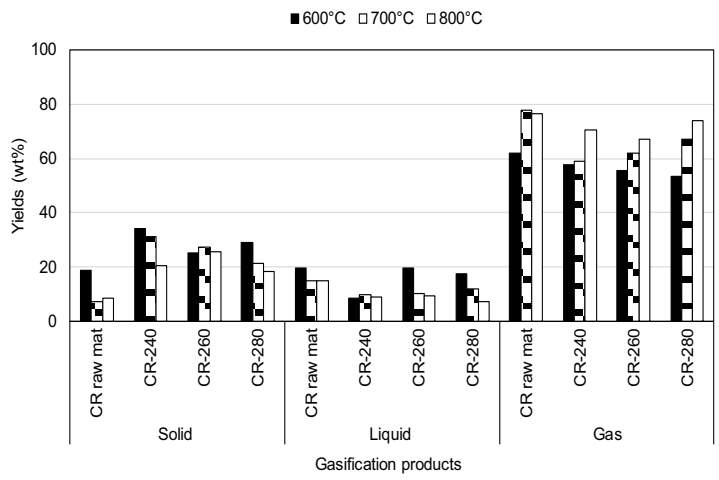

Fig. 3. Products from gasification of CR.

In the CR-260 gasification, hydrogen conversion efficiency to $\mathrm{H}_{2}$ increased with an increase in temperature, as understood from Fig. 4 (a) and (b). Among the CR raw material, CR-260 and CR-280 indicated significant differences in terms of hydrogen conversion to $\mathrm{H}_{2}$ : For CR-260, as gasification temperature increased from $600^{\circ} \mathrm{C}$ to $800^{\circ} \mathrm{C}$, hydrogen conversion changed from $14.11 \%$ to $29.95 \%$ while minimal increase was obtained from the CR raw material. From 600 to $800^{\circ} \mathrm{C}$, the $\mathrm{H}_{2}$ content was increased greatly. The phenomenon of higher $\mathrm{H}_{2}$ gas occurs because of a rapid pyrolysis step when CR is dropped into the reactor. During this step, any available oxygen from $\mathrm{H}_{2} \mathrm{O}, \mathrm{CO}_{2}$, or $\mathrm{CO}$ evolving from the $\mathrm{CR}$ structure itself is adsorbed by the porous CR particle. The trapped oxygen can react with the char and $\mathrm{CO}$ then convert to $\mathrm{CO}_{2}$ at all gasification condition $\left(600-800^{\circ} \mathrm{C}\right)$. Hence, $\mathrm{CO}_{2}$ contributes to the increases in its concentration. In this work, the higher temperature was 
not favourable for $\mathrm{CO}$ production. Hence, the content of $\mathrm{CO}$ decreased with an increase in temperature. This results in a rather steady amount of $\mathrm{CO}$ in the gasification product. CO obtained from the CR gasification is less than the previous works as described in the next section. This is because of the difference in the gasifier set-up and biomass. The $\mathrm{CO}$ concentration in the gas composition of Sadhwani et al.'s (2016) study increased continuously throughout the temperature range. The $\mathrm{CO}$ value changes from $5.8 \%$ up to $11.3 \%$ at a temperature range of $700^{\circ} \mathrm{C}$ to $934^{\circ} \mathrm{C}$. This can be concluded as a result of a difference in the biomass type, gasification, carbon dioxide as an oxidizing medium, and the bubbling fluidized bed gasifier. Additionally, the types of the thermal conversion reactor and the operating conditions, such as the temperature, oxidizing agent, biomass particle size and type of bed/catalyst materials, influence the gas products and yields [6-9].

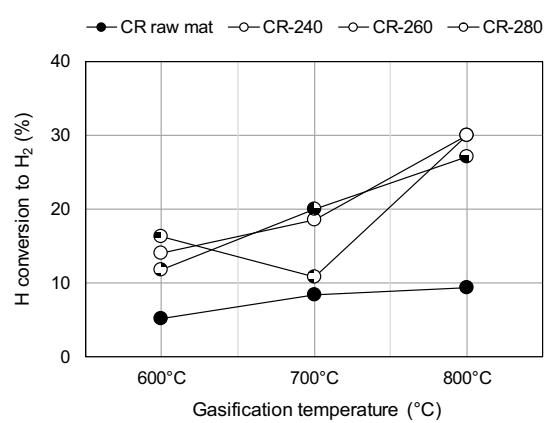

(a)

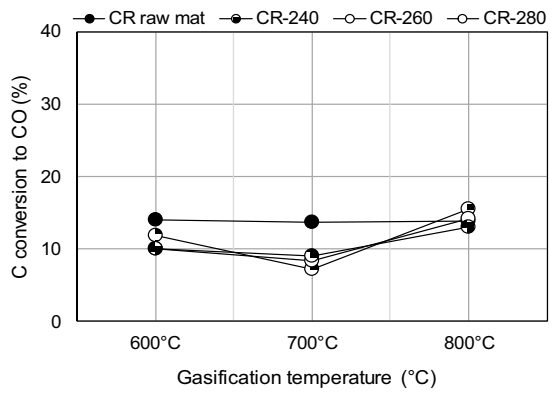

(b)

Fig. 4. Gas product from gasification: (a) Hydrogen conversion to $\mathrm{H}_{2}$ and (b) Carbon conversion to $\mathrm{CO}$.

From the gasification of the $\mathrm{CR}$ raw material, $\mathrm{H}_{2} / \mathrm{CO}$ was lower than that of the torrefied $\mathrm{CR}$ at any condition. The $\mathrm{H}_{2} / \mathrm{CO}$ ratio obtained from the $\mathrm{CR}$ gasification showed a maximum value of 0.61 at $700^{\circ} \mathrm{C}$, while using CR-260 as a raw material yields a much higher ratio of 2.25 at similar gasification conditions. However, the $\mathrm{H}_{2} / \mathrm{CO}$ molar ratio was decreased with an increase in reaction temperature, due to the increase in the concentration of $\mathrm{CO}$. This is because the water-gas shift reaction favors the generation of $\mathrm{CO}$ at a higher temperature. Likewise, Yan et al.'s (2010) work on steam gasification of Pinus char in a fixed-bed reactor reported $\mathrm{H}_{2} / \mathrm{CO}$ ratios of 4.15 and 3.74 at 800 and $850^{\circ} \mathrm{C}$, respectively. It can be noted that the effect of the steam medium in the gasification process improved the carbon conversion efficiency. The fractions of the $\mathrm{CO}, \mathrm{CO}_{2}$, and $\mathrm{H}_{2}$ were influenced by the equilibrium of the water-gas shift reaction. Furthermore, the syngas from the air gasification with $\mathrm{H}_{2} / \mathrm{CO}$ ratio $>2$ 2.5 would be suitable for the Fischer-Tropsch process (gasoline and light olefins synthesis) just as for the case of CR-260 at $700^{\circ} \mathrm{C}$. While the ratio of 1.41 from gasified CR-260 at $600^{\circ} \mathrm{C}$ can be applied in the production of acetic acid, aldehydes, isobutane, isobutanol, and higher alcohols (C1-C6).

\section{Conclusion}

Biomass torrefaction has a positive effect on the product from the subsequent gasification process. The $\mathrm{O} / \mathrm{C}$ and $\mathrm{H} / \mathrm{C}$ from cassava rhizome torrefaction are 0.66 and 0.79 respectively. A lower $\mathrm{O} / \mathrm{C}$ ratio indicates the increased content of $\mathrm{C}$ and a calorific value which implies higher gasification efficiency. The properties of torrefied cassava rhizome is comparable to that of peat, as the heating value of cassava rhizome increased from 15.37 $\mathrm{MJ} / \mathrm{kg}$ to $20.86 \mathrm{MJ} / \mathrm{kg}$. CR torrefaction enhances the gasification, in which hydrogen conversion to $\mathrm{H}_{2}$ increased significantly, which led to improved $\mathrm{H}_{2} / \mathrm{CO}$ when compared with non-torrefied biomass. Further research should focus on the possibility of utilizing the by-products from this process (liquid and gas) to alter the torrefaction atmosphere which may, consequently, improve the efficiency of the overall process as well as the quality of the torrefied solid.

\section{Acknowledgement}

The authors are grateful for the financial support from the Thailand Science Research and Innovation through The Royal Golden Jubilee Ph.D. Programme (Grant No. PHD 0212/2557), National Metal and Materials Technology Center (MTEC), and the Program in Environmental Science (Interdisciplinary Program) Graduate School, Chulalongkorn University.

\section{References}

1. M.J. Prins, K.J. Ptasinski, FJJG Janssen, Energy 31, 3458 (2006)

2. Y-H. Kim, S-M. Lee, H-W, Lee, J.W. Lee, Bioresource technol 116, 120 (2012)

3. Y. Uemura, R. Matsumoto, S. Saadon, Y. Matsumura, Fuel Process. Technol 138, 133 (2015)

4. S. Sirijanusorn, K. Sriprateep, A. Pattiya, Bioresource Technol 139, 343 (2013)

5. K. Homchat, T. Sucharitakul, P. Khantikomol. Energy Procedia 14, 1684 (2012)

6. N. Sadhwani, S. Adhikari, MR. Eden, Ind. Eng. Chem. Res. 55, 10, 2883 (2016)

7. S. Vichaphund, D. Aht-Ong, V. Sricharoenchaikul D. Atong, Environ. Technol. 35, 2254 (2014)

8. A.A. Ahmad, N.A. Zawawi, F.H. Kasim, A. Inayat, A. Khasri, Renewable Sustainable Energy Rev 53, 1333 (2016)

9. F. Yan, S-Y. Luo, Z-Q. B.X. Hu, G. Cheng, Bioresource Technol, 1015633 (2010) 